\title{
Data Management Application Research and Community Service Development Center (P4M) Web Based on STMIK Dipanegara Makassar
}

\author{
Cucut Susanto $^{* 1}$, Nur Salman ${ }^{2}$, Po Abas Sunarya ${ }^{3}$ \\ ${ }^{1,2}$ Teknik Informatika STMIK Dipanegara Makassar, ${ }^{3}$ Teknik Informatika Fakultas Sains \\ dan Teknologi Universitas Raharja \\ Email : ${ }^{* 1}$ cucut@dipanegara.ac.id, ${ }^{2}$ nursalman.halim@dipanegara.ac.id, \\ 3abas@raharja.info
}

\begin{abstract}
STMIK Dipanegara Makassar as an IT campus should rightly maximize the use of technology in an effort to improve the quality and productivity of lecturers and students. One of them is at the Research and Community Service Development Center (P4M) unit that handles the Field Work Plus lectures as well as the Research and Community Service of Internal Lecturers. Where the administration of data management is still using manual methods which of course can cause problems such as lost files, data collection that takes a long time and constrained information dissemination. Therefore, there needs to be an application that can manage administrative data where the application is built in the form of a web so that it can be used as a medium for disseminating information about activities that are the responsibility of P4M. This study uses observations and interviews in gathering data. With this system, P4M no longer needs to use manual methods in managing its administrative data and can use the system as a medium for spreading information.
\end{abstract}

Keywords — Design, P4M, Web, Data Management

\section{INTRODUCTION}

STMIK Dipanegara Makassar is a campus in Makassar that utilizes computer technology in all fields of daily life in the modern era. Utilization has become one of the factors to show the quality of a field. It is fitting for STMIK Dipanegara as an IT campus to maximize the use of technology in an effort to improve the quality and productivity of lecturers and students. Computerized data management also requires less energy compared to when the process is done manually and the time required is shorter.

The Center for Research and Community Service Development (P4M) is a research and community service institution at the STMIK Dipanegara campus. This institution handles activities in which some of them are research management and community service of internal lecturers as well as field work plus lectures. Therefore, a good administrative data management process is needed in order to provide convenience to the P4M, Lecturers, Students and BAAK.

However, the current problem is the process of research administration and community service of internal lecturers and fieldwork plus on the STMIK Dipanegara campus still using the manual method that is using hardcopy files which can certainly cause problems such as files tucked or lost and are constrained in terms of delivering information related to the implementation of research activities and community service of internal lecturers and field work plus. 


\subsection{Software}

The software is a program that contains instructions for data processing. Software as a link between humans as users functions to translate human language into language so that computer hardware understands the user's desires and runs the instructions given and then gives the desired results of humans. "Software is software that contains an instruction that is ordered and processed with the help of hardware so that without software the hardware cannot be used so that software and hardware cannot be separated" ${ }^{[1]}$.

In making this research a literature study needs to be done to be used as a reference from existing studies, including:

1) Research made by Muhaimin Hasanuddin, Eduard HP and Anggi P, entitled "Prototype of the Application of the Web-Based Patient Medical Record System at the Karawaci Medika Clinic" in the study explains the prototype of the web-based application at this clinic making outpatients only need to mention no. Registration to the clinic admin without having to carry outpatient cards and simplify the process of handling outpatients $^{[2]}$.

2) Research conducted by Angelina Efrida Purba, Catur Putro Utomo and Nurjamin entitled "Web-based Village Population System in Cihuni Village, Kec. Kab. Regency Tangerang ". In this study aims to help in addition to processing population data can also store data properly and facilitate the community in terms of service requirements cover letter ${ }^{[3]}$.

3) Research conducted by Ahmad Roihan and Rafida Rahma Fitriani entitled "Web-Based Vehicle Management Knowledge Management Model at Vocational School Motorcycle Workshop". In this study aims to be a solution of the needs of the flow of knowledge (Knowledge) that is not obstructed by time and place constraints ${ }^{[4]}$.

4) Research made by Sutrisno and rohmawati Ningsih entitled "Design and Development of Academic Consultation Information System for Web-Based Department Students in STMIK Prastikom". In this research aims to be able to help lecturer services to the maximum, students are more motivated to complete their studies and reduce the level of student failure in completing their studies ${ }^{[5]}$.

5) Research conducted by Okkita Rizan, Hamidah, Hengki, Novila entitled "Utilization of the Web Framework in Administering Raskin Distribution". In this study concluded that the use of Web Framework such as bootstrap in the Raskin Management Information System that can help Raskin Distribution Implementers in Bintet Belinyu Village in managing Raskin distribution so that the data collection process for Raskin recipients is not too long, there are no double recipient names, difficulties in printing Raskin cards and sending Raskin distribution reports to the Kecamatan coordination team on time ${ }^{[6]}$.

6) Research conducted by Zulfikar, Abdillah f, 2018, "Implementation of the Multiple Keyword Searching Method for Searching Data in P4M STMIK Data Center Applications in Makassar," SKRIPSI, STMIK Dipanegara, Makassar, which has the conclusion that by using the Multiple Keyword Searching method for student data search, the will be easily obtained ${ }^{[7]}$.

\subsection{WWW (World Wide Web)}

World Wide Web (WWW) is a system of accessing information on the internet commonly known as the web.Web uses a protocol called HTTP (HyperText Transfer Protocol) that runs on TCP / IP. By using HyperText, users can easily jump from one document to another, by simply clicking on special texts that were initially marked with an underscore $\mathrm{e}^{[8]}$. "Website is the entire web pages contained in a domain that contains information ${ }^{[9]}$. A website is usually built on many web pages that are interconnected. The relationship between one web page with another web page is called a hyperlink, while the text used as a connecting medium is called hypertext ". According to "Website or site can be interpreted as a collection of pages that are used to display text information, 10 still or motion 
pictures, animations, sounds, and / or a combination of all, both static and dynamic that form a series of interrelated buildings, which each linked to a network of pages " "[10].

\section{3. (HTTP) Hypertext Transfer Protocol}

According to "Hypertext Transfer Protocol (HTTP) is a protocol so that clients and servers can communicate with 10 request-response styles". HTTP determines how the format of the message and how it is sent, and how the web browser acts and reacts to various commands "[11]. HTTP is a protocol that determines the rules that need to be followed by a web browser in requesting or retrieving a document and by the web server in providing documents requested by the web browser. This protocol is designed to transfer files containing hypertext such as files containing HTML used on the World Wide Web, servers from WWW are usually known as HTTPD.

\subsection{XAMPP}

XAMPP stands for X (any four operating systems), Apache, MySQL, PHP, and Perl. XAMPP is a software package that includes Apache Web Server, MySQL database and PHP Interpreter. Web Server on xampp is used to store web documents, this computer will serve web document requests from its clients. Web servers such as explorer or navigator communicate through networks (including internet networks) with web servers, using HTTP. The browser will send a request to the server to request certain documents or other services provided by the server. The server provides the document or service if available also using the HTTP protocol ${ }^{[12]}$.

\subsection{PHP (Perl Hypertext Preprocessor)}

PHP is commonly known as a script programming language that creates HTML documents on the fly that are executed on a web server, HTML documents generated from an application are not HTML documents created using a text editor or HTML editor. The birth of PHP began when Rasmus Lerdorf made a number of Perl scripts that could observe anyone who looked at his curriculum vitae, namely in 1994. These scripts were then packaged into a tool called "Personal Home Page" ${ }^{[13]}$. "PHP: Hypertext Preprocessor is a scripting language used to create dynamic web pages. Dynamic means the page to be displayed is created when the page is requested by the client. This mechanism causes the information received by the client to be always up to date. All PHP scripts are executed on the server where the script is $\operatorname{run}^{\prime[14]}$.

\subsection{MySQL}

MySQL is a database server where data processing occurs on the server and the client only sends data and requests data. MySQL is able to serve quite large data. MySQL is a very popular database used to build web applications that use a database as a source and data processing. MySQL's popularity is possible because of its ease of use, fast query performance and sufficient for the needs of the company's databases. MySQL is a database used by leading sites in Indonesia to store data. MySQL database software is now released as an open source database management which was previously a shareware database software. Shareware is a software that can be distributed freely for personal use / use, but if used commercially, the user must have a license from the manufacturer ${ }^{[14]}$.

\subsection{Research and Community Service Development Center (P4M)}

Center for Research and Community Service Development (P4M) STMIK Dipanegara Makassar as a leading implementing institution in the development of Research and 
Community Service, these institutions are required to play an active role in developing science and technology and to improve community welfare and the nation's competitiveness with research activities and community service, which in turn is a contribution in the effort to solve and overcome the problems of the national community and the world community.

$\mathrm{P} 4 \mathrm{M}$ in managing Research and Community Service based on standards set by the Directorate of Research and Community Service (Dit.Litabmas), Directorate General of Higher Education Ministry of Education and Culture. In line with the active role carried out by P4M in supporting STMIK Dipanegara Makassar towards the Best in the Eastern Indonesia Region, P4M has a research center, and development services, and the tasks undertaken are:

a. Determine the direction of research and community service.

b. Monitor and evaluate the implementation of research and community service.

c. Coordinate research in science and information technology.

d. Coordinate research to develop the conception of national, regional and or regional development through collaboration between universities and or other bodies, both at home and abroad.

e. Conducting dissemination of research results through scientific publications.

f. Coordinate the application of certain scientific, technological and / or artistic research results to support development.

g. Coordinating the implementation of community service to develop the conception of national, regional and / or regional development through collaboration between universities and or other bodies, both at home and abroad.

h. Carry out an inventory and data collection of all research and community service implementation activities at STMIK Dipanegara Makassar.

i. Gathering researchers at STMIK Dipanegara Makassar in a discipline discipline cluster.

j. Coordinate with study programs to ensure the relevance of research and community service activities with educational activities.

k. Control the administration of resources as needed.

P4M STMIK Dipanegara Makassar has achieved excellent institutional quality and performance standards. This is indicated by the following achievements:

a. Scientific publications in the form of accredited National Journal every semester 2 pieces in 2019.

b. There were 4 lecturers attending the international seminar in 2019.

c. Scientific publications in the form of the 2017 National Journal are 4, 2018 is 19, and in 2019 there are 21.

d. The number of IPR / patent in 2019 is 5 pieces.

\subsection{Data Management}

Data comes from the word "Datum" which means facts or parts of facts that contain meaning that is connected with reality that can be described by symbols, numbers, letters and so on. Data is a structured representation of facts. In addition to a description of a fact, data can also represent an object ${ }^{[15]}$. "Data is a value that represents a description of an object or event ${ }^{[16]}$. Thus it can be concluded that "Data Processing is an activity carried out by using input in the form of data and producing useful information for the purpose as planned". 


\section{RESEARCH METHOD}

\subsection{Type of Research}

The type of research conducted by the author in this study, as follows:

a. Field Research

b. Researchers conducted a direct survey on the object of research in this case P4M in obtaining general information about $\mathrm{P} 4 \mathrm{M}$ and specific information that we need in our research.

c. Library Research

d. Researchers in their research read a lot of books and other references to gain knowledge and theoretical basis related to the problems we discussed

\subsection{Data Collection Methods}

Data collection methods used in this study include:

a. Observation

b. Researchers directly observe the implementation of existing activities at STMIK Dipanegara Makassar in this case the fieldwork plus lectures.

c. Interview

d. The writer as a systems analyst conduct interviews to collect data face to face. In this case the authors conducted direct interviews with the P4M chair and BAAK staff.

\subsection{Research Materials}
a. Lecturer Data
b. KKLP data
c. Research Data (Internal)
d. Community Service Data (Internal)

\subsection{Order of Activities}

The stages carried out in the study are as follows:
a. Data collection
b. Software analysis
c. Software design
d. Writing program code
e. Application testing

\section{RESULTS AND DISCUSSION}

\subsection{Use case diagrams}

This system will later handle two administrative processes that are part of P4M (Field Work Plus lectures) activities, namely research and community service for internal lecturers as well as field work plus lectures. Where in this system the P4M can disseminate information regarding the time and implementation requirements and manage data related to KKLP and internal lecturer research. The lecturer can later submit a proposal, see the seminar time if the proposal is approved by P4M. Students can do the registration process and manage daily activities. On the part of the supervisor it can manage the group that becomes its guidance related to daily activities. BAAK can manage administration related to correspondence and conduct KKLP participant seminars. 


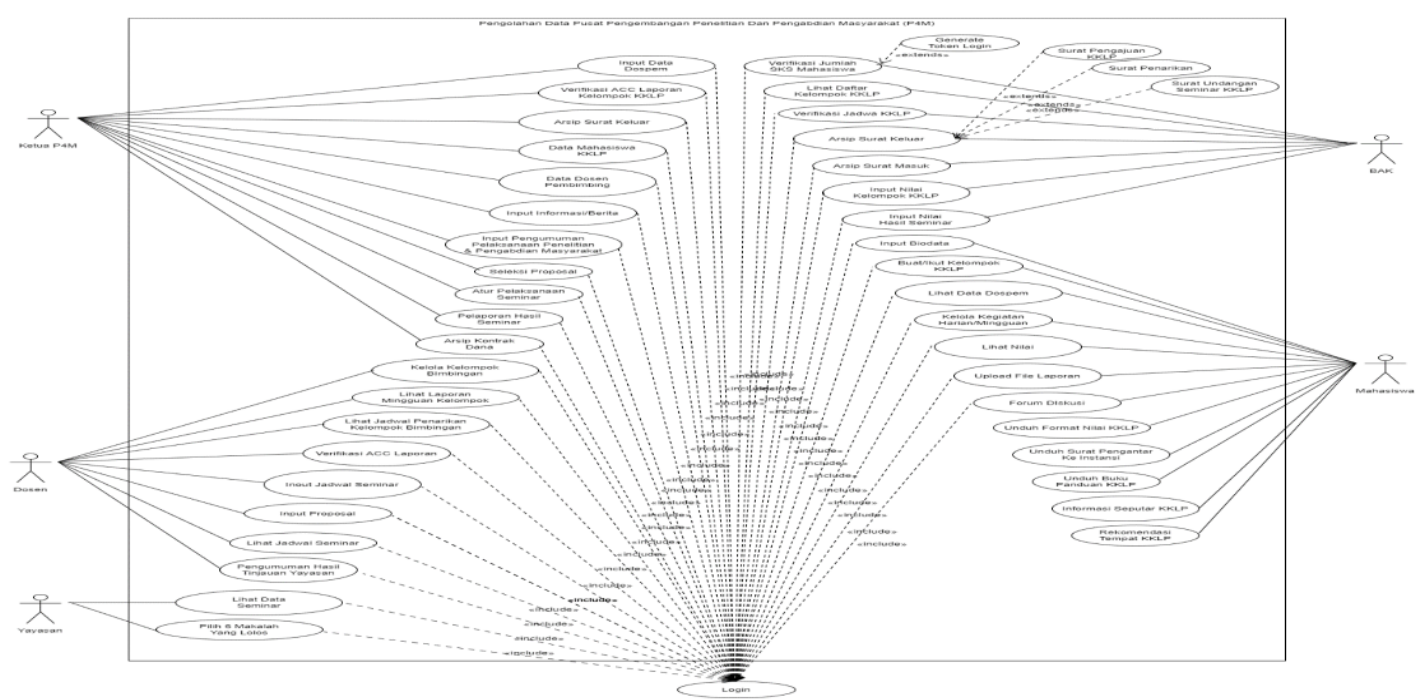

Figure 1. Usecase Diagram P4M

\subsection{Activity Diagram}

A. Activity Login diagram

To access the system the user must first go through the login process, where in the login system there are five different types of access. When opening a web page, a P4M web page will appear, continue to fill in the login form provided if it is wrong, it will return to fill up until it is correct, if it is correct then the user page display will appear.

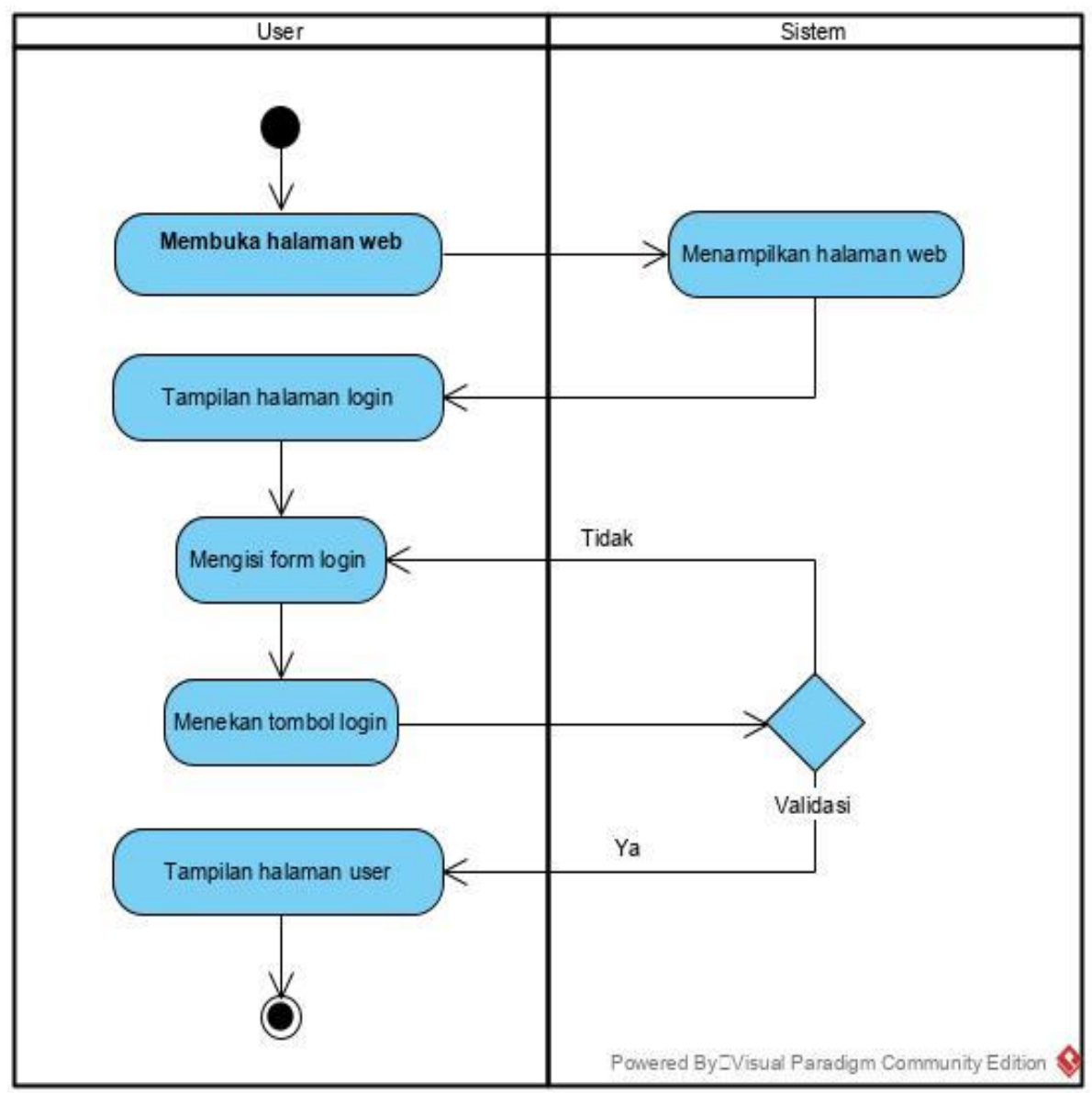

Figure 2. Activity Diagram Login 
B. Activity Diagram of Advisor Lecturer Menu (P4M)

When logging in as $\mathrm{P} 4 \mathrm{M}$ on the $\mathrm{P} 4 \mathrm{M}$ advisor lecturer menu can add, view, edit and delete processes. Select the supervisor lecturer tab and the supervisor lecturer data will appear, if you add a supervisor then select the form plus the supervisor lecturer data continues to fill in the lecturer data form, when finished save it and automatically save it in the available database. If you want to edit the supervising lecturer then click edit the data of the supervising lecturer and continue to edit the wrong lecturer data input and save automatically the edits stored in the database.

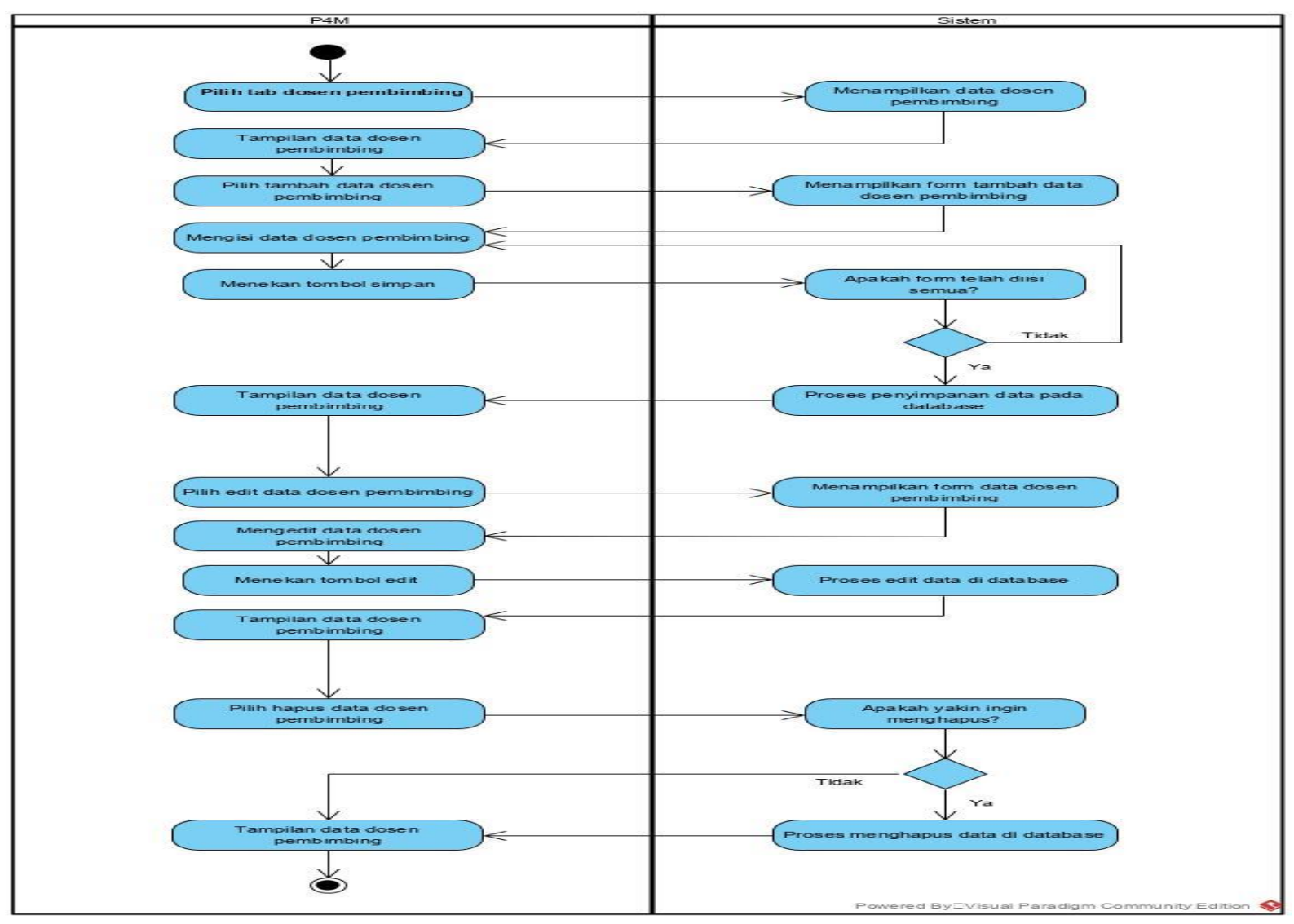

Figure 3. activity diagram Menu Dosen Pembimbing ( P4M)

\subsection{Sequence Diagram}

\section{A. Sequence Diagram P4M (KKLP)}

In this system, P4M as one of the actors can access all the menus when logging in successfully, where each menu has a different data management focus and is carried out in accordance with the sequence of activities. 


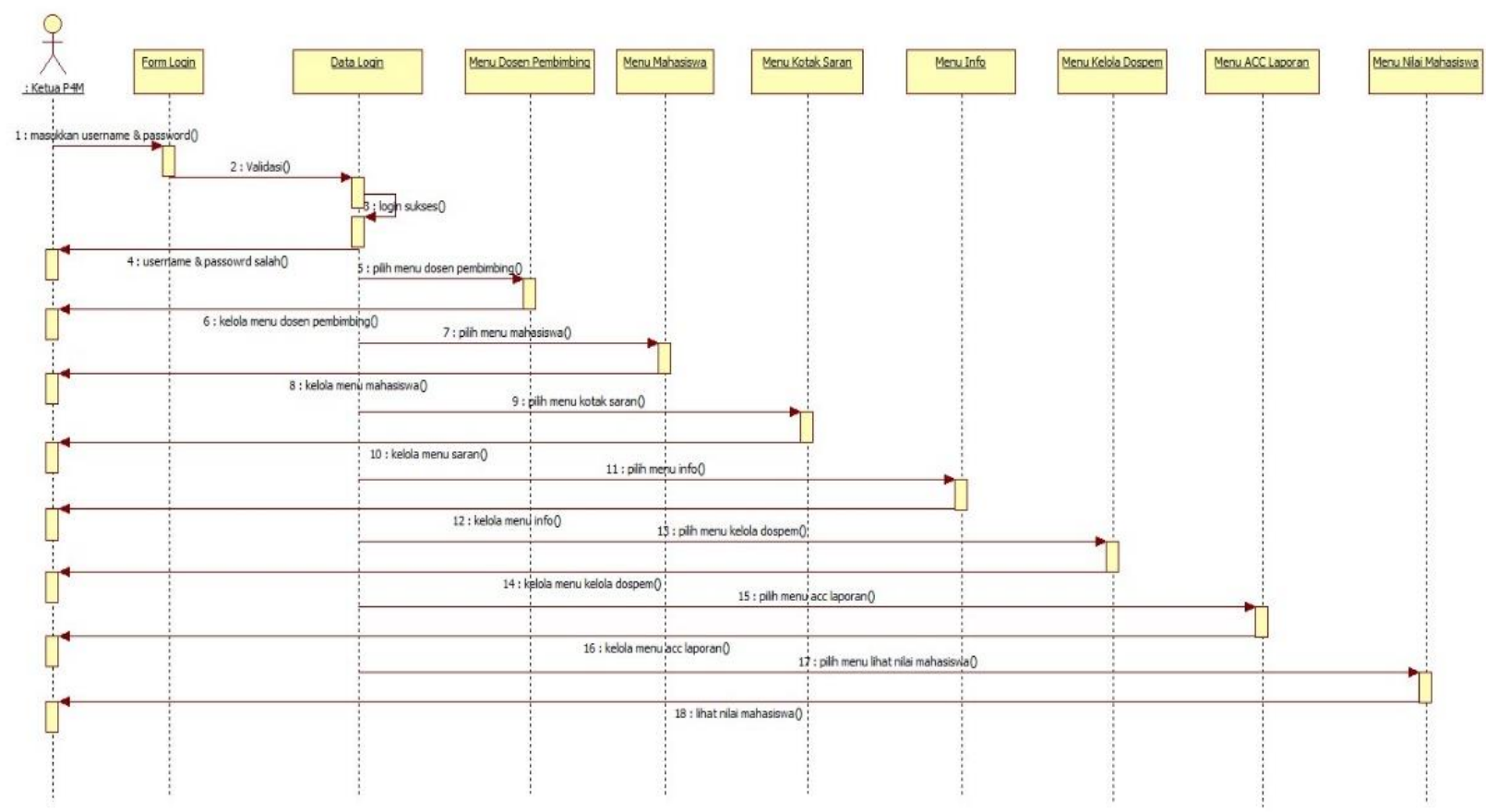

Figure 4. Sequence Diagram P4M

\section{B. P4M Sequence Diagram (Lecturer Research)}

P4M as an actor in Lecturer Research activities has a dashboard menu, input schedule, entry proposal, seminar schedule, send results, contract archive and JUSITI / SISITI when successfully logging in.

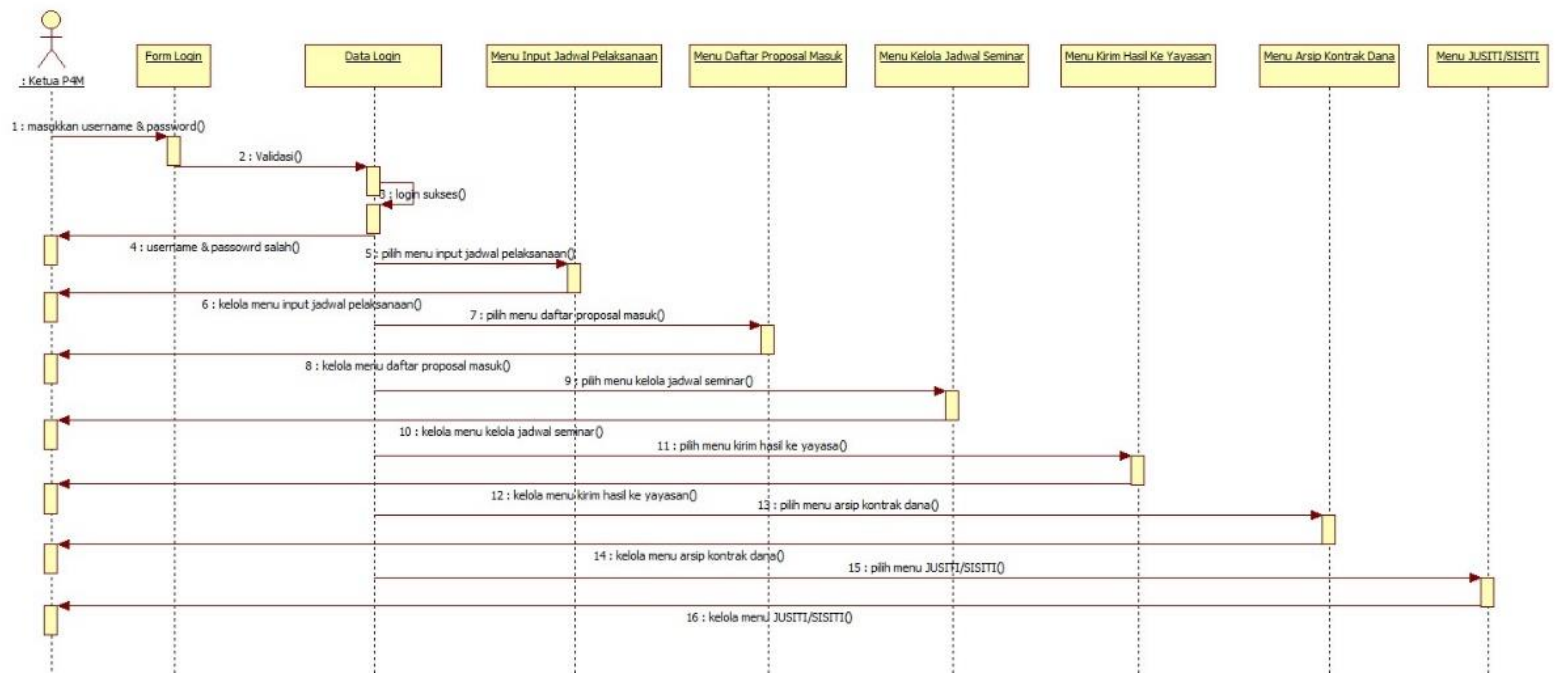

Figure 5. Sequence Diagram P4M

\section{Main Page Design}

On the main menu page design there is info about P4M that can be seen for anyone who accesses this website without having to go through the login process. 




Figure 6. Main Page Design

D. Login Page Design

In the draft login page is a form for users to enter the system.

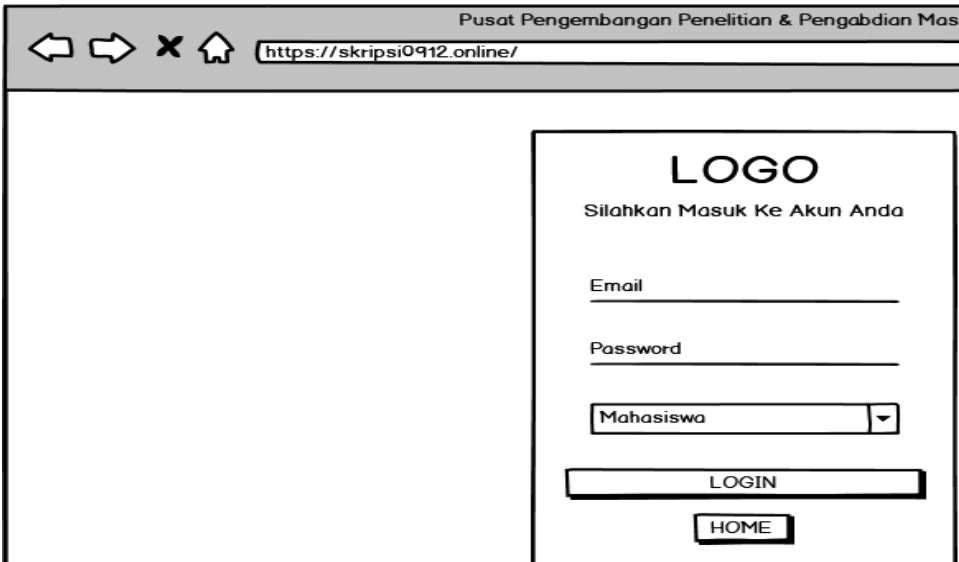

Figure 7. Login Page Design

\section{E. Chat Page Design}

The design of this chat page will be a page where students will discuss with other students related to KKLP activities. 


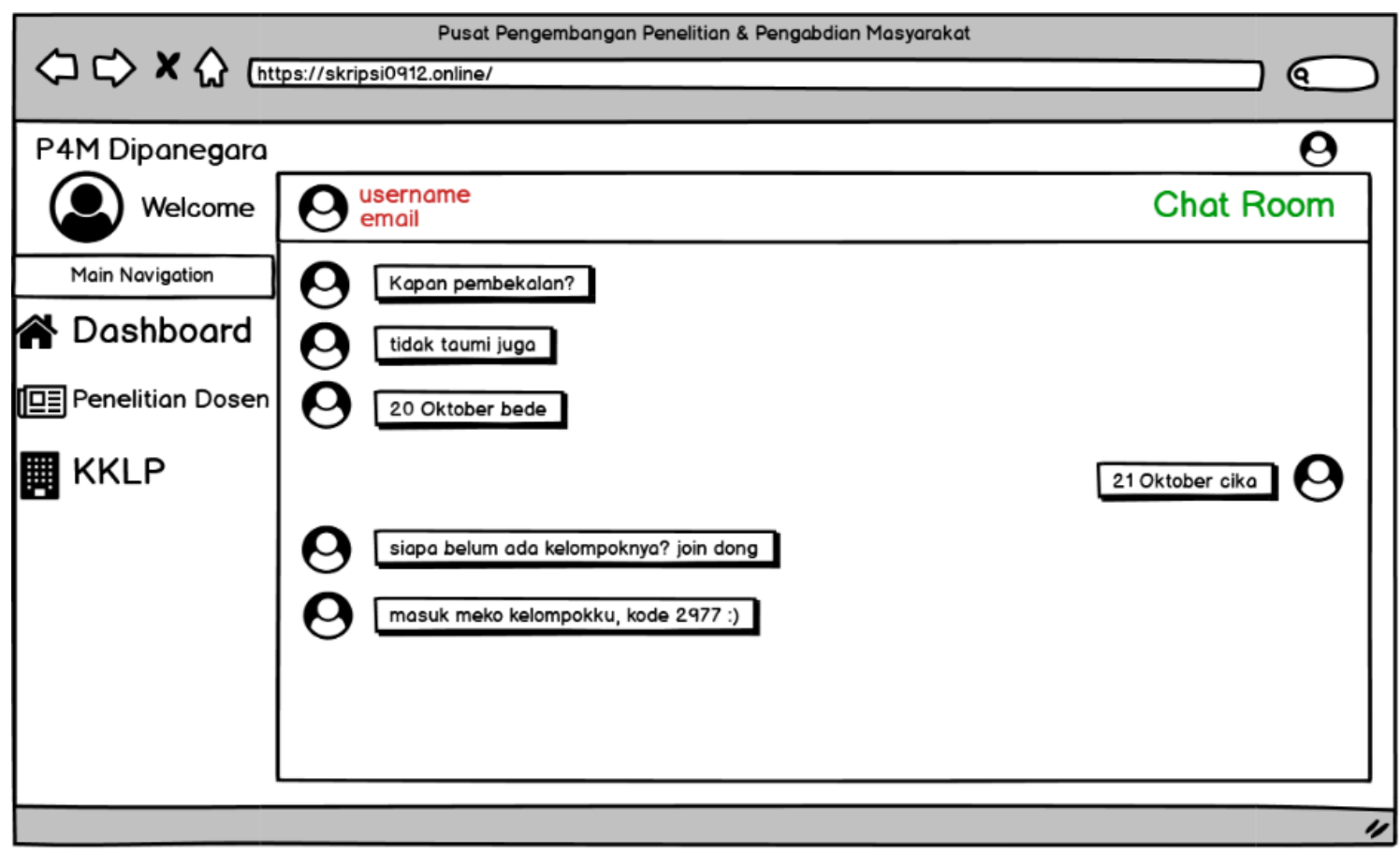

Figure 8. Chat Page Design

F. Design of Data Adding Supervisor Lecturer Data

In the design of the pages added by the data of the supervisor, $\mathrm{P} 4 \mathrm{M}$ will then input the lecturer data.

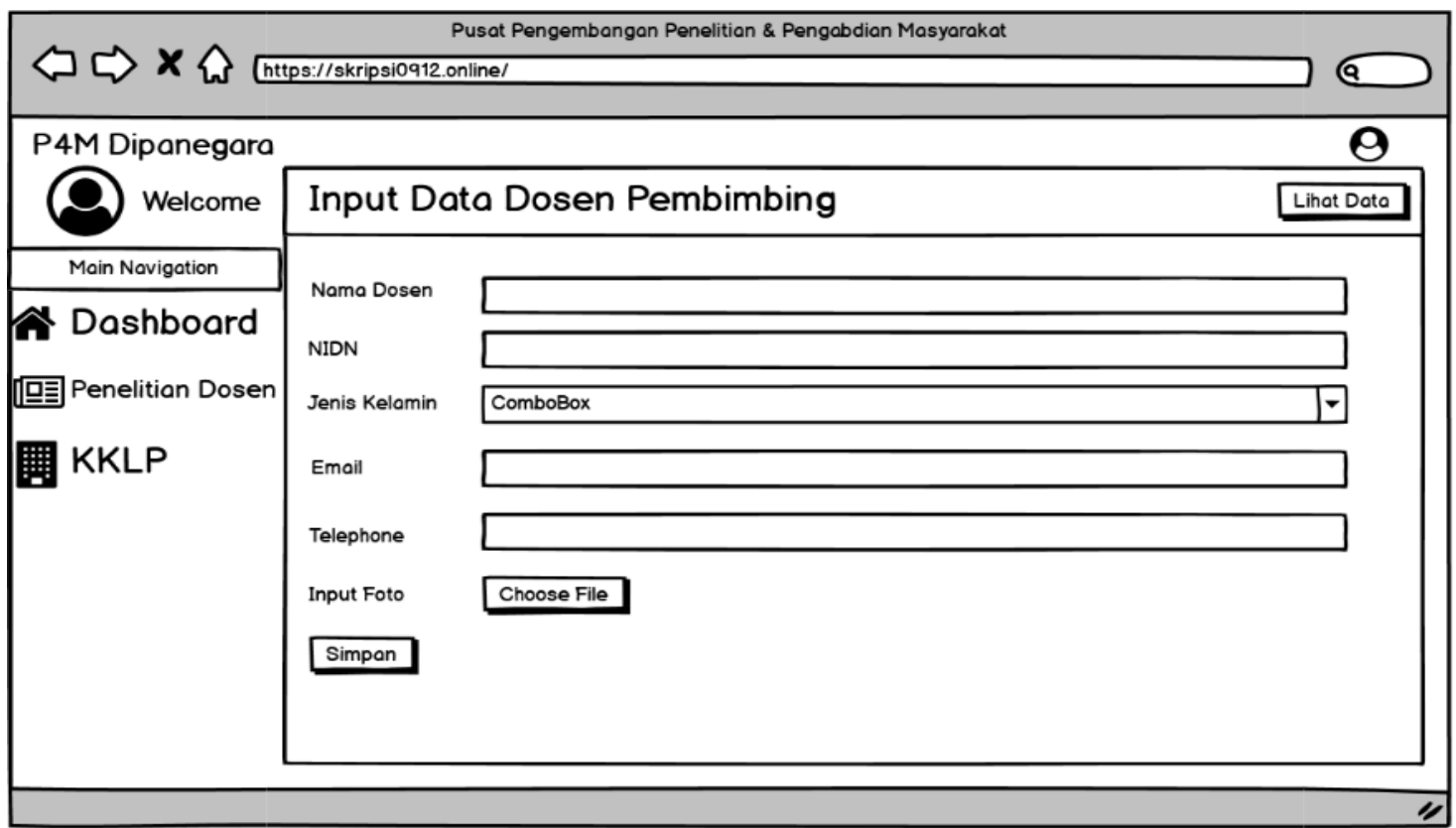

Figure 9. Design of Data Adding Supervisor Lecturer Data

G. Design of Supervising Lecturer Data Page

P4M supervisor lecturer data page design can view lecturer data that has been inputted before. 


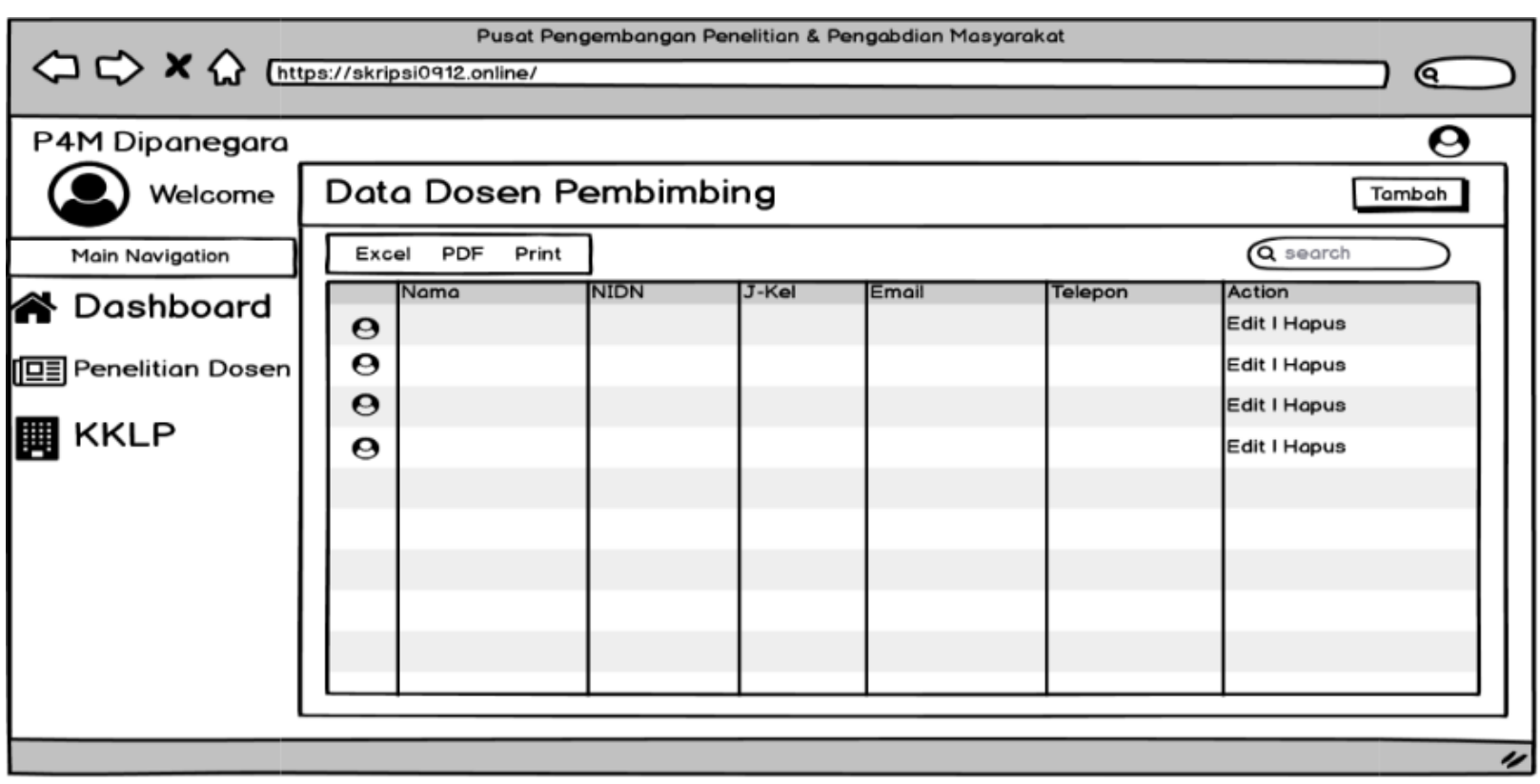

Figure 10. Design of Supervising Lecturer Data Page

H. Page Design Select Supervising Lecturer

On the draft page select the supervisor lecturer, P4M can see the list of lecturers who were subsequently selected to be the guiding lecturers of the KKLP group.



Figure 11. Page Design Select Supervising Lecturer

I. Page Design Assign Supervising Lecturer

On the designation page, assign the supervisor, after $\mathrm{P} 4 \mathrm{M}$ presses the select button on the previous page, the supervisor's data appears in the assign lecturer form and P4M sets it. 


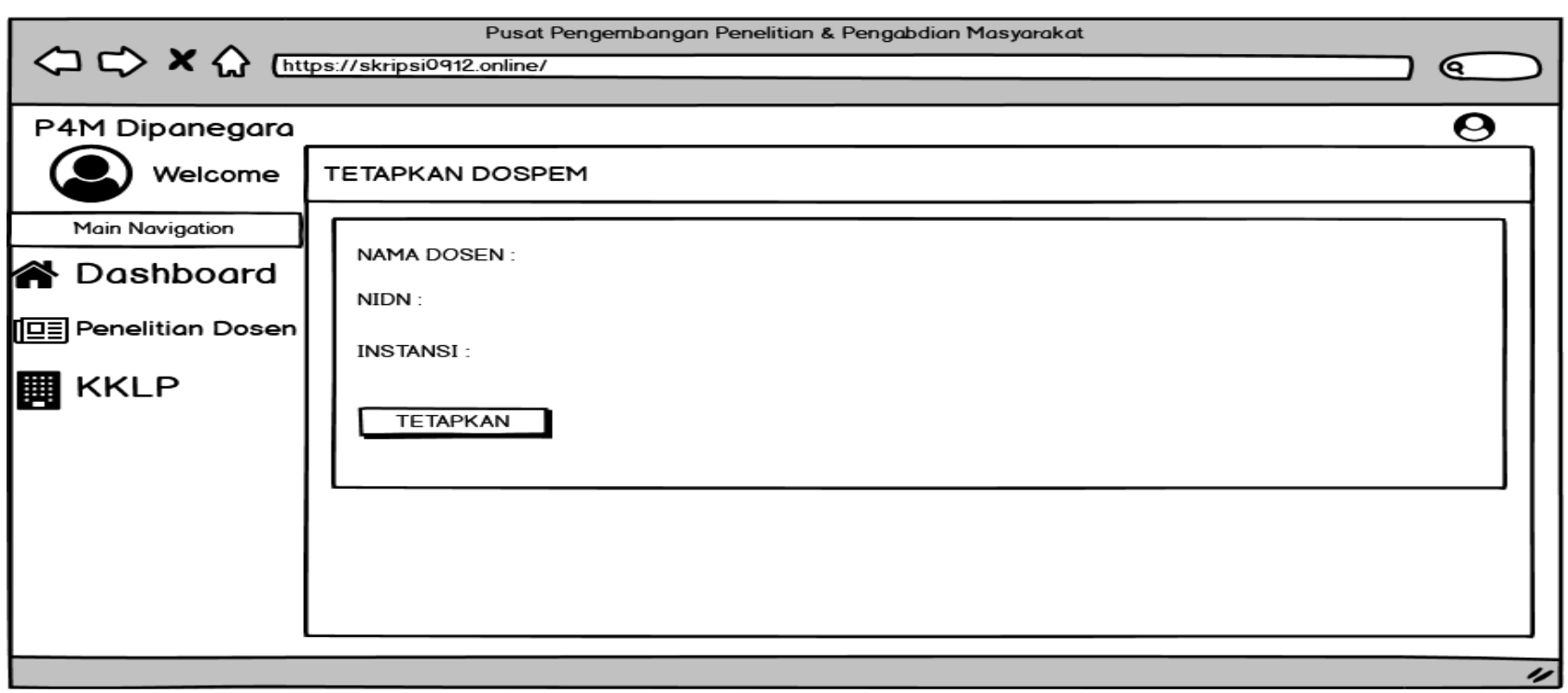

Figure 12. Page Design Assign Supervising Lecturer

\section{CONCLUSION}

Some conclusions that can be drawn from the analysis of the system "Design and Development of Data Management Application Development Center for Research and Community Service (P4M) Web Based on STMIK Dipanegara Makassar" are as follows:

1. Based on the results of existing program testing, the functions of each part of the system are in accordance with what is expected so that this system can be used in managing administrative data related to the Field Work Plus and Lecturer Internal Research activities.

2. This web-based application can be used by the $\mathrm{P} 4 \mathrm{M}$ as a medium for disseminating information about the work unit and the activities for which it is responsible.

\section{SUGGESTED}

In order to obtain better results in the future the authors provide the following suggestions:

1. The author realizes that the application built still has shortcomings. Therefore, it is very necessary to develop ideas in every procedure of implementing activities managed in the system.

2. The author expects the development of platforms in this case android so that application users can more easily access the system

\section{REFERENCES}

[1] Feri H.U., Asnawati, 2015, "Rekayasa Perangkat Lunak", Deepublish, Yogyakarta.

[2] Muhaimin, Eduard H.P dan Anggi P, 2019, "Prototype Aplikasi Sistem Rekam Media Pasien Berbasis Web pada Klinik Karawaci Medika", Jurnal CCIT, Perguruan Tinggi Raharja, Vol 12, No. 1. ISSN : 1978-8282, E-ISSN : 2655-4275. Tangerang.

[3] Angelina Efrida P, Catur Putro Utomo dan Nurjamin, 2017, "Sistem Kependudukan Desa Berbasis Web pada Desa Cinuhi Kec. Pagedangan Kab. Tangerang, Jurnal CCIT, Perguruan Tinggi Raharja, Vol 3, No. 2. ISSN : 1978-8282, E-ISSN : 2655-4275. Tangerang. 
[4] Roihan, Ahmad dan Rafida Rahma Fitriani, 2018, "Pemodelan Knowledge Management Service Kendaraan Berbasis Web pada Bengkel Motor Sekolah Kejuruan, Jurnal CCIT, Perguruan Tinggi Raharja, Vol 4, No. 2. ISSN : 1978-8282, E-ISSN : 2655-4275. Tangerang.

[5] Sutrisno dan Rahmawati Ningsih, 2018, Rancang Bangun Sistem Informsi Akademik Mahasiswa Jurusan Berbasis Web pada STMIK Prastikom, Vol. 4 No. 2, Jurnal CERITA, STMIK Raharja, Tangerang.

[6] Okkita Rizan, Hamidah, Hengki, Novila,2019, "Pemanfaatan Framework Web dalam Pengadministrasian Penyaluran Raskin" Jurnal Sisfotenika, STMIK Pontianak, Vol 9, No. 2, ISSN : 2087-7897, E-ISSN : 2460-5344.

[7] Zulfikar, Abdillah f, 2018, "Implementasi Metode Multiple Keyword Searching Untuk Pencarian Data Pada Aplikasi Data Center P4M STMIK Dipanegara Makassar", Makassar.

[8] Abdul Kadir, 2014, "Edisi Revisi Pengenalan Sistem Informasi”, Andi, Yogyakarta.

[9] Yuhefizar, 2013, "Cara Mudah \& Murah Membangun \& Mengelola Website", Graha Ilmu, Yogyakarta

[10] Hikmah, Agung Baitul, dkk, 2015, "Cara Cepat Membangun Website dari Nol Studi Kasus : Web Dealer Motor", CV Andi Offset, Yogyakarta.

[11] Jauhari Khairul Kawistara, \& Priyanto Hidayatullah, 2015, "Pemrograman Web", Penerbit Informatika, Bandung.

[12] Surniawan, \& Eri Mardiani, 2014, “Aplikasi Penjualan Dengan Visual Basic, Xampp, dan Data Reaport", PT Elek Media Komputindo,Jakarta.

[13] Betha Sidik, 2017, "Pemrograman Web dengan PHP 7", Informatika, Bandung.

[14] Abdul Kadir, 2013, "Buku Pintar Programmer Pemula PHP”, Mediakom, Yogyakarta.

[15] Vercellis, 2009, "Data Warehousing, in Business Intelligence", onlinelibrary.wiley.com.

[16] Setiawan, Wawan. \& Munir, 2006, "Pengantar Teknologi Informasi : Basis Data", Bandung : Universitas Pendidikan Indonesia. 